\title{
Antidiabetic Activities and Identification of Chemical Compound from Samama (Anthocephalus macrophyllus (Roxb) Havil)
}

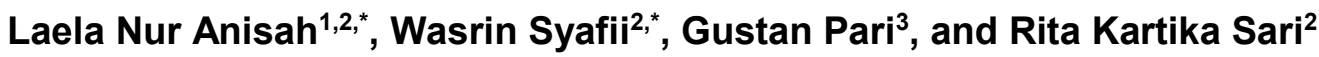 \\ ${ }^{1}$ Ministry of Environment and Forestry, Manggala Wanabakti building, Block I $7^{\text {th }}$ Floor, \\ Jl. Jenderal Gatot Subroto, Jakarta 10270, Indonesia \\ ${ }^{2}$ Department of Forest Products, Faculty of Forestry, Bogor Agricultural University (IPB), \\ Kampus IPB Dramaga, Bogor 16680, Indonesia
}

${ }^{3}$ Research and Development of Forest Engineering and Forest Products Processing, Ministry of Environment and Forestry, Jl. Gunung Batu No. 5, Bogor 16610, Indonesia

Received May 31, 2017; Accepted August 31, 2017

\begin{abstract}
Samama (Anthocephalus macrophyllus) is one of a pioneer indigenous fast growing species in Indonesia which have been used as traditional medicine for various diseases. The objectives were to determine the extract yield, to analyze their antidiabetic activity by inhibition assay for $\alpha$-glucosidase enzyme activity and analysis chemical with GCMS. Extraction of leaves, bark and wood samples were done by using ethanol $95 \%$. Fractionation the most active bark ethanol extract was conducted by using n-hexane and ethyl acetate. The yield of ethanol extracts in leaves, bark and wood were 13.90, 12.87, and $2.18 \%$ respectively. Based on antidiabetic activity assay, the bark ethanol extract was the most active extract by the $I C_{50}$ value of $5.86 \mu \mathrm{g} / \mathrm{mL}$. Phytochemical analysis on bark ethanol extracts showed that they contained flavonoid, quinone, triterpenoid, saponin, tannin and coumarin which were assumed have high contribution in antidiabetic activities. The result of fractionation ethanol extract bark showed that the ethyl acetate fraction was the most active fraction (IC $506.82 \mu \mathrm{g} / \mathrm{mL}$ ). GCMS analysis in ethyl acetate fraction indicated the presence of phenolic compounds such as antiarol, phenol and Scopoletin in which were estimated have antidiabetic activity. Isolation using column chromatography and identification of compounds from ethyl acetate fraction using NMR and LC-ESI-QT of afforded compound 1 Scopoletin which having antidiabetic activity with $I C_{50} 13.37 \mu \mathrm{g} / \mathrm{mL}$. Until now there is no publication about antidiabetic activity of Scopoletin from Samama. These results indicate that the compound Scopoletin from ethyl acetate fraction Samama bark was a potential source of antidiabetic agents.
\end{abstract}

Keywords: Anthocephalus macrophyllus; antidiabetic; $\alpha$-glucosidase; ethyl acetate fraction; Scopoletin

\section{ABSTRAK}

Samama (Anthocephalus macrophyllus) adalah salah satu jenis pohon pionir cepat tumbuh asli Indonesia yang telah digunakan sebagai obat tradisional berbagai macam penyakit. Penelitian bertujuan untuk menentukan kadar ekstraktif, aktivitas diabetesnya melalui uji penghambatan aktivitas enzim a-glukosidase dan analisis komponen kimia dengan GCMS. Ekstraksi daun, kulit dan kayu menggunakan etanol 95\%. Fraksinasi ekstrak etanol kulit teraktif menggunakan $n$-heksana dan etil asetat. Rendemen ekstrak etanol daun, kulit dan kayu adalah 13,90, 12,87, dan 2,18\%. Berdasarkan uji aktivitas antidiabetes, ekstrak etanol kulit merupakan ekstrak teraktif dengan nilai $I C_{50}$ $5,86 \mu \mathrm{g} / \mathrm{mL}$. Analisis fitokimia ekstrak etanol kulit menunjukkan kandungan flavonoid, kuinon, triterpenoid, saponin, tanin dan kumarin yang diduga berperan dalam aktivitas antidiabetesnya. Fraksinasi ekstrak etanol kulit menghasilkan fraksi etil asetat yang teraktif $\left(I C_{50} 6,82 \mu \mathrm{g} / \mathrm{mL}\right)$. Analisis GCMS terhadap fraksi etil asetat mengindikasikan keberadaan beberapa senyawa fenolik seperti pirokatekol, antiarol, fenol dan Skopoletin yang diduga memiliki aktivitas antidiabetes. Isolasi menggunakan kolom kromatografi dan identifikasi senyawa dari fraksi etil asetat menggunakan NMR dan LC-ESI-QTof menghasilkan senyawa 1 Skopoletin yang memiliki aktivitas antidiabetes dengan nilai $I C_{50} 13,37 \mu \mathrm{g} / \mathrm{mL}$. Sampai saat ini belum dilaporkan aktivitas antidiabetes senyawa Skopoletin dari Samama. Hasil penelitian ini menunjukkan bahwa senyawa Skopoletin dari fraksi etil asetat kulit Samama merupakan sumber potensial bahan alam sebagai antidiabetes.

Kata Kunci: Anthocephalus macrophyllus; antidiabetes; $\alpha$-glukosidase; fraksi etil asetat; Skopoletin

* Corresponding author.

Email address : ella.aniez@gmail.com, wasrinsy@indo.net.id 


\section{INTRODUCTION}

Diabetes mellitus (DM) is a metabolic disorder that stills a major health in the world, including Indonesia which is characterized by high blood sugar levels (hyperglycemia) because of either insulin deficiency or insulin resistance or both [1]. In 2013 the number of diabetes patients in the world was 382 million and increased by the value of 415 million people in 2015 . The number would be increase into 642 million people in 2040. Indonesia reached 10 million people of DM patients [2-3].There is different types of DM. Out of all types, approximately $90 \%$ of DM patients is type II DM or non-insulin dependent diabetes mellitus patients [4].

Oral medicines is one way of diabetes treating by lowering blood sugar levels. In general, diabetes drugs based on synthetic chemicals have many side effects such as hepatotoxicity, abdominal pain, flatulence, diarrhea and hypoglycemia [5]. An increasing number of diabetes patients, various side effects of diabetes medicinal based on synthetic chemicals and also the high price of diabetes treatment have encouraged researchers to explore and identify new antidiabetic drugs. One is through the exploration of bioactive compounds from natural medicinal materials, particularly herbs that have been used traditionally to treat diabetic. Extract or plant secondary metabolites is one of the chemical components of plants that can be used for various purposes such as natural medicine. Various studies have shown that extract in plants have antidiabetic [6-8].

One of fast-growing tree species in Indonesia that is potentially to be developed as natural antidiabetic medicine is Samama (Anthocephalus macrophyllus (Roxb) Havil). Samama tree is a pioneer species native from Indonesia which is classified into Rubiaceae family [9]. The utilization of Samama as a traditional medicine in Indonesia has not been widely reported and was limited in North Maluku Indonesia, Halawane et al. [10] reported that Samama leaves and bark have been used as traditional medicine by local people for enhancing body stamina, reducing fatigue, lowering cholesterol and improving women fertility.

Based on the author knowledge, until now, we have not found any research on antidiabetic activity of Samama tree. Research on antidiabetic activity obtained from another spesies in the same genus Anthocephalus cadamba has been conducted [11-12]. The ethanol extract of $A$. cadamba bark have a significant effect in lowering blood glucose levels by the value of $23.8 \%$ on the animal testing mice [12].

One of therapy approach for treating diabetes is through the inhibition of a-glucosidase enzyme in the digestive organs to suppress post-prandial hyperglycemia by delaying the absorption of glucose, hyperglycemia control and reducing chronic vascular complications in diabetic patients [13-15]. $\alpha-$ glucosidase enzyme inhibitor is one of the alternative medicine approach to type 2 diabetes mellitus [16].

There are various groups of active compounds from plants that have $\alpha$-glucosidase inhibitor activity, such as flavonoids, alkaloids, terpenoids, saponins, tannins, anthocyanins, glycosides, phenolic compounds and other [8,17-18]. The ethanol extract of A. cadamba leaves contained compounds groups such as flavonoid, hydroquinone, saponins, tannins, alkaloids, terpenoids and steroids. It is very active in inhibiting a-glucosidase enzymes with $\mathrm{IC}_{50} 7.24 \mu \mathrm{g} / \mathrm{mL}$ [19]. The existence of extractive substances or specific chemical compounds could be found in several species of the same genus [20].

The active compounds content is influenced by parts of the tree such as leaves and bark [21]. Therefore, it is necessary to study the content and bioactivity of antidiabetic extractive substances which is contained in various parts of the Samama tree.

These objectives of the research were to determine the extract yield and antidiabetic activity of several parts of Samama tree and identification of chemical compounds by Gas Chromatography Mass Spectrophotometry (GCMS), Liquid Chromatography (LC)-ESI-QTof and Nuclear Magnetic Resonance (NMR). Antidiabetic activity test was performed by inhibition assay for $\alpha$-glucosidase enzyme activity. The results are expected to be an additional reference in the development of natural antidiabetic medicine.

\section{EXPERIMENTAL SECTION}

\section{Materials}

Material in this research were leaves, bark and wood from 6 years-old Samama tree which was planted in Bogor (its geographical coordinates are $6^{\circ} 39^{\prime} 22.4^{\prime \prime}$ South, $106^{\circ} 43^{\prime} 54.9^{\prime \prime}$ East, average elevation $663 \mathrm{~m}$ ), West Java, Indonesia and identified at the Herbarium Bogoriense Botany Division, Research Center for Biology, Indonesian Institute of Sciences.

Chemical materials were ethanol, $n$-hexane, ethyl acetate, methanol, dichloromethane, acetone, silica gel, sodium bicarbonate, phosphate buffer, dimethylsulfoxide (DMSO) purchased from Merck Chemicals, aquadest, methanol, whereas $\rho$ nitrophenyl-a-D-glucopyranoside ( $\rho-\mathrm{NPG})$, quercetin, enzyme a-glucosidase purchased from Wako Pure Chemical Industry Ltd (Osaka, Japan). 


\section{Instrumentation}

The instruments in this research were Willey Miller, mesh screen, macerator, funnel separator, vacuum rotary evaporator, reaction tube, water bath, chamber, spectrometer UV-Vis Agilent Technologies Cary 60 series, Gas Chromatography-Mass Spectrometry (GCMS) Pyrolysis Shimadzu QP2010 series, Gravitation Chromatography Column, Thin Layer Chromatography, Preparative Layer Chromatography, (LC)-ESI-QTof, Nuclear Magnetic Resonance (NMR) JEOL JNM-ECA $500 \mathrm{MHz}$.

\section{Procedure}

\section{Sample extraction}

Powder samples (leaves, bark, wood) of Samama tree $(50 \mathrm{~g})$ were extracted by maceration in $500 \mathrm{~mL}$ ethanol $95 \%$ for $24 \mathrm{~h}$ at room temperature. Remaceration was repeated until the filtrate colorless. The solvent was evaporated by using vacuum rotary evaporator at $40{ }^{\circ} \mathrm{C}$. In order to determine the content of extractives, the densed extract $(5 \mathrm{~mL})$ was dried in the oven at $103^{\circ} \mathrm{C}$, while the rest of the densed extract was dried in the oven at $40{ }^{\circ} \mathrm{C}$ for further testing.

\section{Preliminary phytochemical analysis}

The qualitative phytochemical were conducted based on standard procedure [22]. Phytochemical analysis is committed to detect the presence of compounds group such as alkaloid, flavonoid, saponin, triterpenoid or steroid, tannin, hydroquinone and coumarin. Phytochemical analysis was performed on the powder sample from different parts of the Samama tree (leaves, bark, wood) and also on the most active ethanol extract that inhibit the a-glucosidase enzyme activity.

Test for alkaloid. Powder samples (1 g) or plants extracts $(0.1 \mathrm{~g})$ was dissolved in $10 \mathrm{~mL} \mathrm{CHCl}_{3}$ and added some drops of $\mathrm{NH}_{4} \mathrm{OH}$. The solution was filtered and the filtrate was put into a test tube. The $\mathrm{CHCl}_{3}$ extracts in a test tube was shaken with 10 drops of $\mathrm{H}_{2} \mathrm{SO}_{4} 2 \mathrm{M}$. The $\mathrm{H}_{2} \mathrm{SO}_{4}$ fraction was taken, and then added reagents of Meyer, Dragendorff and Wagner. If there were white color deposits with Meyer reagent, an orange red precipitant with Dragendorff reagent and brown precipitant with Wagner reagent, it showed the presence of alkaloids.

Test for flavonoid. Powder samples (1 g) or plants extracts $(0.1 \mathrm{~g})$ was taken in a test tube, added $10 \mathrm{~mL}$ of hot water and boiled for $5 \mathrm{~min}$. The solution was filtered and the filtrate was put into a test tube. Further to the filtrate was added $0.5 \mathrm{mg}$ powder, $1 \mathrm{~mL}$ of concentrated $\mathrm{HCl}, 1 \mathrm{~mL}$ of amyl alcohol and shaken vigorously. The presences of flavonoids were characterized by red, yellow or orange colors.
Test for saponin. Powder samples $(1 \mathrm{~g})$ or plants extracts $(0.1 \mathrm{~g})$ was taken in a test tube, added $10 \mathrm{~mL}$ of hot water and boiled for $5 \mathrm{~min}$. The solution was filtered and the filtrate was put into a test tube. Further shaken by hand for $10 \mathrm{sec}$ and allowed to stand for 10 min. A foam layer was obtained on the top of the test tube. The presence of saponins was characterized by the formation of stable foam.

Test for triterpenoid/steroid. Powder samples $(1 \mathrm{~g})$ or plants extracts $(0.1 \mathrm{~g})$ was dissolved in $25 \mathrm{~mL}$ ethanol, heated and filtered. The filtrate was evaporated and added ether. The ether fraction was pippetted and tested on a spot plates. The filtrate was added Libermann Burchard reagents ( 3 drops of acetic anhydride and 1 drop of concentrated $\mathrm{H}_{2} \mathrm{SO}_{4}$ ). If there were formed red/purple color it showed the presence of triterpenoids. Otherwise, if the green or blue color was formed, it showed the presence of steroid.

Test for tannin. Powder samples (1 g) or plants extracts $(0.1 \mathrm{~g})$ was added $10 \mathrm{~mL}$ of water and boiled for $5 \mathrm{~min}$. The solution was filtered and the filtrate was put into a test tube. The filtrate was added $\mathrm{FeCl}_{3} 1 \%$. If there were formed of blue or green blackish, it showed the presence of tannin.

Test for hydroquinone. Powder samples (1 g) or plants extracts $(0.1 \mathrm{~g})$ was dissolved in methanol and filtered. The solution was filtered and the filtrate was put into a test tube. The filtrate was added one drop of $\mathrm{NaOH} 10 \%$. If there were formed of red color, it showed the presence of hydroquinone.

Test for coumarin. Powder samples (1 g) or plants extracts $(0.5 \mathrm{~g})$ was taken in a test tube, added $10 \mathrm{~mL}$ chloroform and placed funnel at the mouth of the test tube (funnel hole covered with cotton soaked with water). The solution was heated for $20 \mathrm{~min}$ over a water bath and then cooled. The solution was filtered with filter paper and the filtrate was evaporated until dry. Subsequently the residue was added $10 \mathrm{~mL}$ of hot water and cooled. The solution was put into a test tube and added $0.5 \mathrm{~mL}$ of $10 \% \mathrm{NH}_{4} \mathrm{OH}$. The solution was observed under UV light beam wavelength of $366 \mathrm{~nm}$. Blue or green fluorescence indicated coumarin.

\section{Inhibition assay for $\alpha$-glucosidase enzyme activity}

Antidiabetic activity assay was carried out based on the ability of the extract to inhibit the enzyme $\alpha$ glucosidase activity through enzymatic reactions [6, 13]. The stock solution of the extract sample were prepared in dimethyl sulfoxide (DMSO) at concentration of $40 \mu \mathrm{g} / \mathrm{mL}$. Various of the extract solution concentration $(5,10,25,50$ and $100 \mu \mathrm{g} / \mathrm{mL})$ were prepared by diluting the stock solution in DMSO. The extract sample solution $(5 \mu \mathrm{L})$ at various of extract concentration, substrate $\rho$-nitrophenyl glucopyranoside $(\rho-N P G) 5 \mathrm{mM}(250 \mu \mathrm{L})$ and phosphate buffer $100 \mathrm{mM}$ 
pH $7.0(495 \mu \mathrm{L})$ were mixed in reaction tube. The mixture was preincubated at $37{ }^{\circ} \mathrm{C}$ for $5 \mathrm{~min}$. Then, $250 \mu \mathrm{L}$ a-glucosidase enzyme from Saccharomyces cerevisiae were added into the mixture. The mixture was incubated at $37{ }^{\circ} \mathrm{C}$ for $15 \mathrm{~min}$. The enzyme reaction was stopped by adding $\mathrm{Na}_{2} \mathrm{CO}_{3} \quad 0.2 \mathrm{M}(1 \mathrm{~mL})$. The absorbance of the reaction mixture was measured immediately by spectrophotometer UV Vis at $400 \mathrm{~nm}$ wavelength. The blank solution was prepared by mixing DMSO, phosphate buffer, $\rho-N P G$, without the addition of the extract sample. Control solution was prepared both with enzymes and without enzymes. Quercetin was used as a reference solution with various concentrations (1$10 \mu \mathrm{g} / \mathrm{mL})$. The percentage inhibitory activity was calculated as:

$[(\Delta \mathrm{C}-\Delta \mathrm{E}) / \Delta \mathrm{C}] \times 100 \%$

where, $C$ is the absorbance of the control solution, $E$ is the absorbance of the extract sample solution.

The Inhibitor Concentration $\left(\mathrm{IC}_{50}\right)$ value was calculated by logarithmic regression equation analysis between the percentage inhibition and concentration of the extract. Antidiabetic activity could be determined by the $I_{50}$ value that is the concentration of $\alpha$-glucosidase enzyme inhibitor that could inhibit $50 \%$ of its activity under the assay conditions [6]. The extract is classified as very active if it has $I_{50}$ value less than $10 \mu \mathrm{g} / \mathrm{mL}$, while classified as active and inactive if the $\mathrm{IC}_{50}$ value are between $10-100 \mu \mathrm{g} / \mathrm{mL}$ and larger than $100 \mu \mathrm{g} / \mathrm{mL}$, respectively [23].

\section{Extract partition}

The dried bark $(750 \mathrm{~g})$ was extracted with $7.5 \mathrm{~L}$ ethanol $95 \%$ for three times at room temperature. The solvent was evaporated using vacuum rotary evaporator. The ethanol extract partitioned with $n$-hexane and ethyl acetate, respectively. The $n$-hexane and ethyl acetate solvent were evaporated by using vacuum rotary evaporator.

\section{Chemical components analysis by GCMS}

Chemical components analyses of the most active fractions were detected using a Gas ChromatographyMass Spectrometry (GC-MS) Pyrolysis Shimadzu Pyr-
GCMS QP2010 series. Samples were pyrolyzed at $400{ }^{\circ} \mathrm{C}$ for $10 \mathrm{sec}$. This instrument worked on injection temperature at $280{ }^{\circ} \mathrm{C}$, detector temperature at $280{ }^{\circ} \mathrm{C}$, the initial temperature of column at $50{ }^{\circ} \mathrm{C}$ with increased $15{ }^{\circ} \mathrm{C} / \mathrm{min}$ to $280{ }^{\circ} \mathrm{C}$. Software data analysis GC-MS were used in data processing. Identification of compounds were completed by comparing the data in the mass spectrum with existing data in the $7^{\text {th }}$ WILEY library.

\section{Chemical compound isolation from ethyl acetate extract}

The ethyl acetate extract (3.02 g) was fractionated and isolated on silica gel column chromatography and eluted by $n$-hexane : dichloromethane, dichloromethane : ethyl acetate; ethyl acetate : methanol by gradient. The fraction with the best spot data was further purification using preparative layer chromatography (PLC) with dichloromethane : ethyl acetate (9:1).

\section{Chemical compound analysis by NMR and LCMS/MS}

Chemical compounds analysis were detected using a Nuclear Magnetic Resonance (NMR) JEOL JNM-ECA 500. The NMR spectra were recorded at 500 $\mathrm{MHz}$ for ${ }^{1} \mathrm{H}$ with $\mathrm{CDCl}_{3}$ as the solvent. The mass spectra were measured with Xevo G2-XS QTof (Waters) instrument.

\section{RESULT AND DISCUSSION}

\section{Phytochemical Analysis of Samama Powder Samples}

The qualitative phytochemical analysis in all powder samples from Samama leaves, bark and wood showed that several of compounds group which were detected are alkaloid, flavonoid, quinone, steroid, triterpenoid, saponin, tannin, and coumarin (Table 1). Based on some studies of several researchers that compound groups such as flavonoid, alkaloid, terpenoid, saponin, tannin, anthocyanin, glycosides, and

Table 1. Phytochemical analysis

\begin{tabular}{lcccc}
\hline \multirow{2}{*}{ Compounds group } & \multicolumn{2}{c}{ Parts of Samama tree (powder) } & Ethanol extract \\
\cline { 2 - 5 } & Leaf & Bark & Wood & Bark \\
\hline Alkaloid & - & - & + & - \\
Flavonoid & + & + & + & + \\
Hydroquinone & + & + & + & + \\
Triterpenoid & + & + & + & + \\
Steroid & + & - & - & - \\
Saponin & - & + & + & + \\
Tannin & + & + & - & + \\
Coumarin & - & + & - & + \\
\hline
\end{tabular}



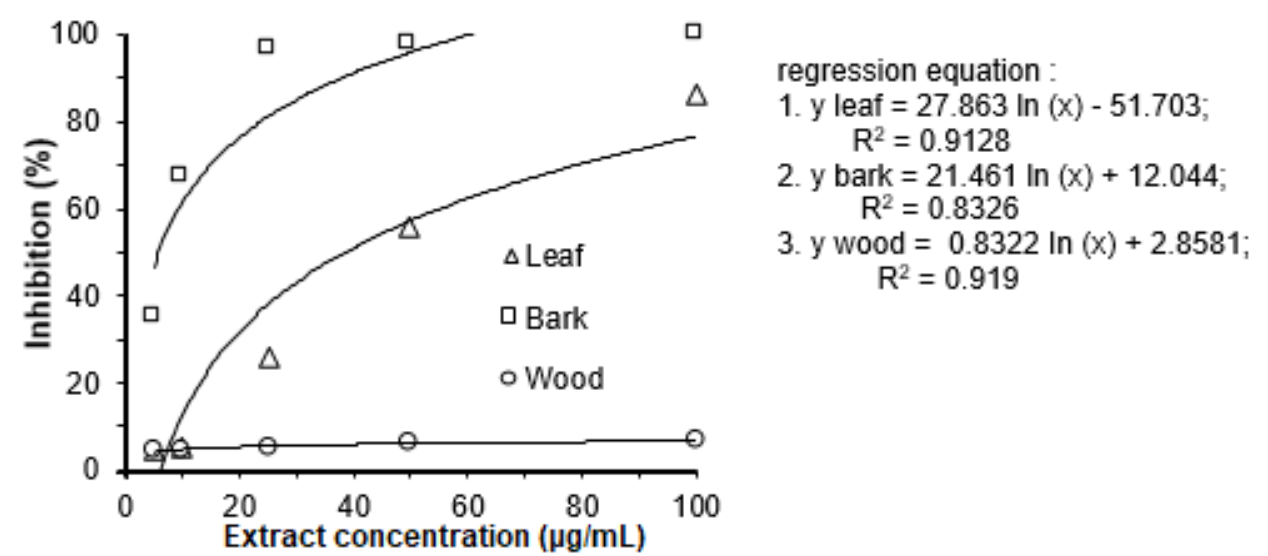

Extract concentration $(\mu \mathrm{g} / \mathrm{mL})$

Fig 1. Correlation between ethanol extract Samama concentration and the percentage of a-glucosidase enzyme inhibition

Table 2. $\mathrm{IC}_{50}$ values and antidiabetic activity of the ethanol extracts from Samama

\begin{tabular}{llc}
\hline \multicolumn{1}{c}{ Extract } & $\begin{array}{c}\left.\mathrm{IC}_{50}{ }^{*}\right) \\
(\mu \mathrm{g} / \mathrm{mL})\end{array}$ & $\begin{array}{c}\text { Enzyme } \alpha \text {-glucosidase } \\
\left.\text { inhibition activity }{ }^{* *}\right)\end{array}$ \\
\hline Leaf & 38.49 & active \\
Bark & 5.86 & very active \\
Wood & $>100$ & inactive \\
\hline Note: $\left.{ }^{*}\right)$ the average of 3 replicates & with quercetin control $\left(\mathrm{IC}_{50}\right.$ of \\
$\left.4.83 \mu \mathrm{g} / \mathrm{mL}) ;{ }^{* *}\right)$ Darmawan $[23]$ &
\end{tabular}

phenolic have a-glucosidase enzyme inhibitor activity $[8,17-18,24]$. Based on Table 1, the various parts of Samama tree (leaves, bark, wood) considered as a potential inhibitor for the enzyme a-glucosidase activity.

\section{Antidiabetic Activity of Ethanol Extract of Samama}

The yield of ethanol extract ranged from 2.18$13.90 \%$. The highest yield was resulted from the extraction of the leaf $(13.90 \%)$, followed by bark extract $(12.87 \%)$ and wood extract $(2.18 \%)$. The difference of extract yield indicated that the content of extractive substances varied widely among different parts of the tree although they were extracted by the same solvent [20]. The high yield of leaves ethanol extract was due to the presence of chlorophyll compounds in the leaves which were extracted by ethanol solvent [21-22]. Chlorophyll can be dissolved in organic solvents such as ethanol, acetone, methanol, ether and chloroform [22]. The bark has higher extract content than wood. It was due to the content of the lipophilic and hydrophilic compounds in the bark which were higher than wood. The same phenomenons were observed by Anisah et al. [19] on leaves, bark and wood extract of Jabon (Anthocephalus cadamba).

The results in antidiabetic activity by inhibition assay for $\alpha$-glucosidase enzyme showed that the extract ethanol from Samama tree had capability to inhibit $\alpha$ glucosidase enzyme. The color and characteristic of
Table 3. I $\mathrm{C}_{50}$ values and antidiabetic activity of the fraction from ethanol extract partition Samama bark

\begin{tabular}{lcc}
\hline \multicolumn{1}{c}{ Fraction } & $\begin{array}{c}\left.\mathrm{IC}_{50}{ }^{*}\right) \\
(\mu \mathrm{g} / \mathrm{mL})\end{array}$ & $\begin{array}{c}\text { Enzyme } \alpha \text {-glucosidase } \\
\left.\text { inhibition activity }{ }^{* *}\right)\end{array}$ \\
\hline$n$-hexane & $>100$ & inactive \\
ethyl acetate & 6.82 & very active \\
residue & 11.41 & active \\
\hline Note: ${ }^{*}$ ) the average of 3 replicates; ${ }^{* *}$ ) Darmawan [23]
\end{tabular}

each ethanol extract from leaves, bark and stem were different visually. Fig. 1 shows that increasing the concentrations of the extract could increase the percentage inhibition of a-glucosidase enzyme activity. However, there were differences in the response of $\alpha$ glucosidase enzyme inhibition by the three different kinds extracts. This indicated that the compounds content of each extract varied in types and compositions. This was supported by the results of Anisah et al. [19] researched on A. cadamba extract. There were reported that the differences in various parts of the ethanol extract of $A$. cadamba (leaves, bark, wood) shows different responses antidiabetic bioactivity.

Antidiabetic activity can be determined from the $I_{50}$ value. There were differences $I C_{50}$ values and antidiabetic activity of ethanol extracts from different parts of Samama tree (Table 2). Ethanol extract of Samama bark had the highest anti-diabetic activity $\left(\mathrm{IC}_{50} 5.86 \mu \mathrm{g} / \mathrm{mL}\right)$. It was very active in inhibition $\alpha-$ glucosidase enzyme activity. Leaves extract was classified as active ( $\mathrm{IC}_{50} 38.49 \mu \mathrm{g} / \mathrm{mL}$ ), while the wood extract was considered not active inhibitors. The high antidiabetic bioactivity of the ethanol extract of Samama bark was predicted because of the presence active compounds from group compounds such as flavonoid, quinone, triterpenoid, tannins, saponin and coumarin (Table 1). The flavonoid compounds such as 


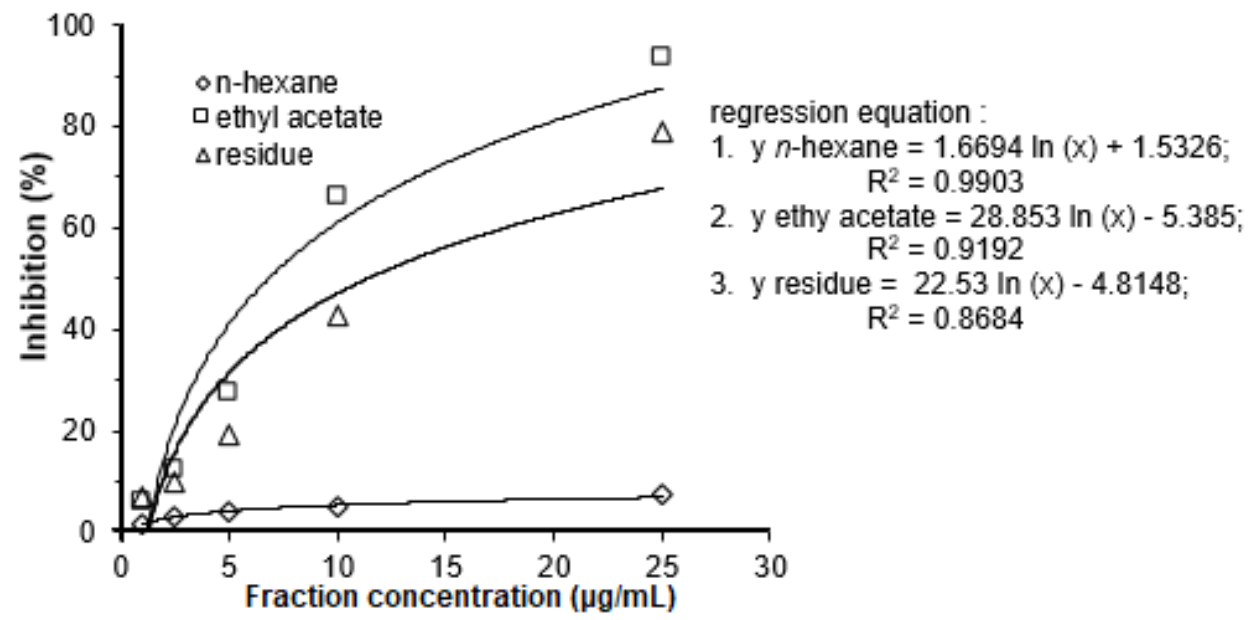

Fig 2. Correlation between fraction concentration from fractionated ethanol extract Samama bark and the percentage of $\alpha$-glucosidase enzyme inhibition

Table 4. Estimated chemical compounds in ethyl acetate fraction based on GC-MS analysis

\begin{tabular}{clc}
\hline No & \multicolumn{1}{c}{ Compound } & $\begin{array}{c}\text { Relative concentration } \\
(\%)^{*}\end{array}$ \\
\hline 1 & Pyrocatechol & 25.78 \\
2 & Antiarol & 20.91 \\
3 & 4- Methyl Catechol & 9.97 \\
4 & Phenol & 5.89 \\
5 & Scopoletin & 2.01 \\
\hline${ }^{*}$ Relative concentration of 20 detected compounds
\end{tabular}

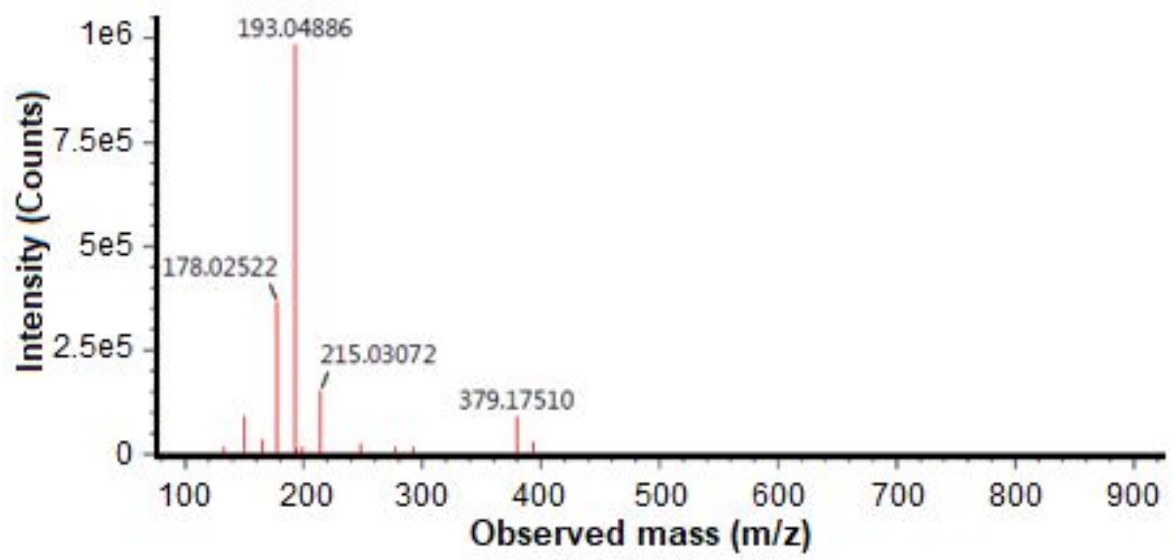

Fig 4. Mass spectra of compound $1\left(\mathrm{~m} / \mathrm{z}\right.$ 193.0488, $\left.[\mathrm{M}+\mathrm{H}]^{+}\right)$, LC-ESI-Qtof spectra)

anthocyanin, isoflavone and flavonol [14] and hydroquinone can inhibit the enzyme a-glucosidase activity [25].

\section{Antidiabetic Activity of $\boldsymbol{n}$-Hexane Extract of Samama Bark}

Ethanol extract partition by $n$-hexane resulted $n$ hexane extract yield about $4.70 \%$ and the highest extract yield was resulted from residue $(64.34 \%)$. We could<smiles></smiles>

Fig 3. Chemical structure of compound 1 Scopoletin [33] observe that residue contained large amount of compounds which could not dissolved in $n$-hexane and ethyl acetate solvents. It indicated that Samama bark contained large amount of polar rather than non-polar extractives.

Table 3 and Fig. 2 shows that $n$-hexane fraction had no antidiabetic activity (inactive) with $\mathrm{IC}_{50}$ values $>100 \mu \mathrm{g} / \mathrm{mL}$, whereas residue had antidiabetic activity with $\mathrm{IC}_{50}$ values $11.41 \mu \mathrm{g} / \mathrm{mL}$ (active). 
Table 5. ${ }^{1} \mathrm{H}-\mathrm{NMR}$ data of compound $1\left({ }^{1} \mathrm{H}, 500 \mathrm{MHz}\right)$ and Scopoletin

\begin{tabular}{cll}
\hline \multirow{2}{*}{ Position } & $\begin{array}{l}\text { Compound 1 } \\
\boldsymbol{\delta}_{\mathrm{H}}(\text { mult., } \boldsymbol{J ~ H z})\end{array}$ & $\begin{array}{l}\text { Reference [33] } \\
\boldsymbol{\delta}_{\mathrm{H}}(\text { mult., } \mathbf{J ~ H z})\end{array}$ \\
\hline 1 & - & - \\
2 & $6.28(\mathrm{~d}, 1 \mathrm{H}, 9.08)$ & $6.25(\mathrm{~d}, 1 \mathrm{H}, 9.75)$ \\
3 & $7.61(\mathrm{~d}, 1 \mathrm{H}, 9.73)$ & $7.84\left(\mathrm{~d},{ }^{1} \mathrm{H}, 9.75\right)$ \\
4 & - & - \\
5 & $6.93(\mathrm{~s}, 1 \mathrm{H})$ & $7.19(\mathrm{~s}, 1 \mathrm{H})$ \\
6 & - & - \\
7 & - & - \\
8 & $6.85(\mathrm{~s}, 1 \mathrm{H})$ & $6.79(\mathrm{~s}, 1 \mathrm{H})$ \\
9 & - & - \\
10 & $3.96(\mathrm{~s}, 3 \mathrm{H})$ & $3.90(\mathrm{~s}, 3 \mathrm{H})$ \\
\hline
\end{tabular}

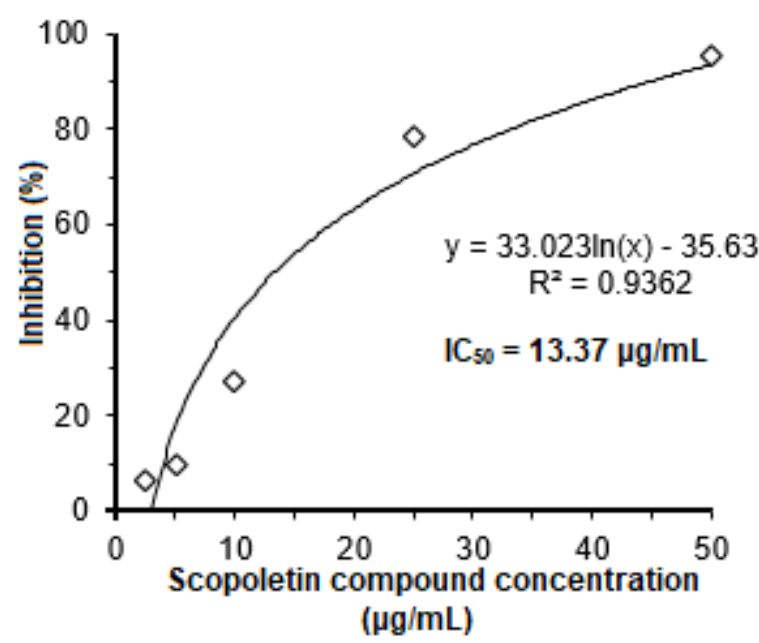

Fig 5. Correlation between Scopoletin concentration from ethyl acetate fraction Samama bark and the percentage of a-glucosidase enzyme inhibition

\section{Antidiabetic Activity of Ethyl Acetate Extract of Samama Bark}

Ethyl acetate fraction was the most active extract with $\mathrm{IC}_{50}$ values of $6.82 \mu \mathrm{g} / \mathrm{mL}$ and extract yield of $30.97 \%$ (Table 3, Fig. 2). Thus, the ethyl acetate fraction was a very prospective fraction to be developed as an antidiabetic agent.

Chemical components analyses of ethyl acetate fraction by Pyrolysis GC-MS are presented in Table 4. The results showed that the ethyl acetate fraction contained compounds such as pyrocatechol (25.78\%), antiarol $(20.91 \%)$, 4-methyl catechol $(9.97 \%)$, phenol $(5.89 \%)$ and Scopoletin $(2.01 \%)$. Although pyrocatechol is the dominant compound, Wang et al. [26] reported that pyrocatechol did not show a-glucosidase inhibitory activity $\left(\mathrm{IC}_{50}>1000 \mu \mathrm{M}\right)$. Otherwise, Scopoletin was detected in small amounts, but this compound have strong a-glucosidase enzyme inhibitory activity [27-29]. Phenolic compounds derived from phenylpropanoyl esters of catechol glycoside have anti-hyperglycemic activity in streptozotocin induced diabetic rats [30].

a-glucosidase enzyme plays a vital role in maintaining the normal physiological function and participates in carbohydrate metabolism that specifically hydrolyzes the a-glucopyranoside bond to release glucose from the non-reducing end of the sugar [31]. The effective a-glucosidase enzyme inhibitors can significantly retard the dietary complex carbohydrate digestion and decrease the post prandial effect of carbohydrate consumption on blood glucose levels [32].

Fractionation and isolation of ethyl acetate extracts using silica gel column chromatography given fifteen fractions (F1-F15). Fraction F4 is the fraction with the best spot data based on Thin Layer Chromatography (TLC). Purification of F4 was done using preparative layer chromatography (PLC) to afford a coumarin derivative $1(5.1 \mathrm{mg})$. Characterized of the chemical structure of compound 1 was conducted by combined the 1D-NMR $\left({ }^{1} \mathrm{H}\right)$ spectral data (Table 5) with molecular weight data.

The molecular formula of compound 1 was determined by LC-ESI-QTof MS as $\mathrm{C}_{10} \mathrm{H}_{8} \mathrm{O}_{4}(\mathrm{~m} / \mathrm{z}$ 193.04879, $[\mathrm{M}+\mathrm{H}]^{+}$) as presented in Fig. 3 and 4.

The ${ }^{1} \mathrm{H}$-NMR spectrum showed four aromatic protons $\left(\delta_{H} 6.28,6.85,6.93,7.61 \mathrm{ppm}\right)$ and one methoxy group $\left(\left(\delta_{H} 3.96 \mathrm{ppm}\right)\right.$ (Table 5)). Based on the spectroscopic data, molecular weight data and reference comparative [33], compound $\mathbf{1}$ was identified as Scopoletin, a coumarin derivative compound (Fig. 3).

Until now there is no publication about Scopoletin of Samama. Based on Fig. 5, Scopoletin from Samama bark has strong antidiabetic activity with an $\mathrm{IC}_{50}$ of $13.37 \mu \mathrm{g} / \mathrm{mL}$ (active). Lee et al. [27] also reported that Scopoletin from Morinda citrifolia, the same family with Samama (Rubiaceae) inhibited a-glucosydase enzyme activity with an $\mathrm{IC}_{50}$ of $9.7 \mu \mathrm{g} / \mathrm{mL}$. Scopoletin also showed signification reduction in blood glucose level in streptozotocin induced diabetic rats [29].

\section{CONCLUSION}

The present study have demonstrated the potential of Samama the indigenous fast growing tree species in Indonesia as sources of a-glucosidase enzyme inhibitor. Screening phase on various parts of Samama tree (leaves, bark, wood) were identified to have antidiabetic activity. The extract ethanol of Samama bark showed very active inhibition for $\alpha$ glucosidase enzyme. In the stratified partition of Samama bark ethanol extract, ethyl acetate fraction was the most active fraction as a-glucosidase enzyme 
inhibitor. It contained phenolic compounds were estimated to have antidiabetic activity.

Isolation and identification chemical compound of ethyl acetate fraction result to give one of the phenolic compounds contained in the Samama bark, that is Scopoletin, a coumarin derivative compound. Until now there is no publication about Scopoletin of Samama. In this research, Scopoletin from Samama bark could inhibit $\alpha$-glucosidase enzyme activity with an $\mathrm{IC}_{50}$ of 13.37 $\mu \mathrm{g} / \mathrm{mL}$ (active). This compound was promising source of $\alpha$-glucosidase enzyme inhibitor.

\section{ACKNOWLEDGEMENT}

The authors would like to thank the Ministry of Environment and Forestry and the Directorate for Research and Community Service of the Ministry of Research, Technology and Higher Education for the Republic of Indonesia for the research grant with the cooperation contract number: 079/SP2H/LT/DRPM/II/ 2016, 17 February 2016.

\section{REFERENCES}

[1] American Diabetes Association, 2010, Diagnosis and Classification of Diabetes Mellitus, Diabetes Care, 33 (Suppl. 1), S62-S69.

[2] International Diabetes Federation, 2013, IDF Diabetes Atlas $6^{\text {th }}$ ed., Brussels.

[3] International Diabetes Federation, 2015, IDF Diabetes Atlas $7^{\text {th }}$ ed., Brussels.

[4] International Diabetes Federation, 2014, About Diabetes, http://idf.org/ABOUT-DIABETES.

[5] Islam, M.N., Jung, H.A., Sohn, H.S., Kim, H.M., and Choi, J.S., 2013, Potent $\alpha$-glucosidase and protein tyrosine phosphatase 1B inhibitors from Artemisia capillaris, Arch. Pharmacal Res., 36 (5), 542-552.

[6] Kim, Y.M., Wang, M.H., and Rhee, H.I., 2004, A novel a-glucosidase inhibitor from pine bark, Carbohydr. Res., 339 (3), 715-717.

[7] Pasaribu, F., Sitorus, P., and Bahri, S., 2012, Uji ekstrak etanol kulit buah manggis (Garcinic mangostana L.) terhadap penurunan kadar glukosa darah, J. Pharm. Pharmacol., 1 (1), 1-8.

[8] Kumar, S., Saini, M., Kumar, V., Prakash, O., Arya, R., Rana, M., and Kumar, D., 2012, Traditional medicinal plants curing diabetes: a promise for today and tomorrow, Asian J. Tradit. Med., 7 (4), 178-188.

[9] Ogata, K., Fujii, T., Abe, H., and Baas, P., 2008, Identification of the Timbers of Southeast Asia and the Western Pacific, Kaiseisha Press., Hiyosshidai, Japan, 400.
[10] Halawane, J.E., Hidayah, H.N., and Kinho, J., 2011, Prospek Pengembangan Jambon Merah (Anthocephalus macrophyllus (Roxb.) Havil), Solusi Kebutuhan Kayu Masa Depan, Environment and Forestry Research and Development Institute of Manado, 20.

[11] Gurjar, H., Jain, S.K., Irchhaiya, R., Nandanwar, R., Sahu V.K., and Saraf, H., 2010, Hypoglycemic effects of methanolic extract of Anthocephalus cadamba bark in alloxan induced diabetic rats (Rox B) Miq, Int. J. Pharm. Sci. Res., 1 (3), 79-83.

[12] Bussa, S.K., and Pinnapareddy, J., 2010, Antidiabetic activity of stem bark of Neolamarckia cadamba in alloxan induced diabetic rats, Int. J. Pharm. Technol., 2 (2), 314-324.

[13] Dewi, R.T., Tachibana, S., and Darmawan, A., 2014, Effect on a-glucosidase inhibition and antioxidant activities of butyrolactone derivatives from Aspergillus terreus MC751, Med. Chem. Res., 23 (1), 454-460.

[14] Kumar, S., Narwal, S., Kumar, V., and Prakash, O., 2011, a-glucosidase inhibitors from plants: A natural approach to treat diabetes, Pharmacogn. Rev., 5 (9), 19-29.

[15] Meng, P., and Zhou, X., 2012, a-Glucosidase inhibitory effect of a bioactivity guided fraction GIB638 from Streptomyces fradiae PWH638, Med. Chem. Res., 21, 4422-4429.

[16] Jong-Anurakkun, N., Bhandari, M.R., and Kawabata, J., 2007, a-Glucosidase inhibitors from Devil tree (Alstonia scholaris), Food. Chem., 103 (4), 1319-1323.

[17] Yin, Z., Zhang, W., Feng, F., Zhang, Y., and Kang, W., 2014, a-Glucosidase inhibitors isolated from medicinal plants, Food Sci. Human Wellness, 3 (34), 136-174.

[18] Patel, M.B., and Mishra, B., 2011, Hypoglycemic activity of alkaloidal fraction of Tinospora cordifolia, Phytomedicine, 18 (12), 1045-1052.

[19] Anisah, L.N., Syafii, W., Sari, R.K., and Pari, G., 2015, Aktivitas antidiabetes ekstrak etanol Jabon (Anthocephalus cadamba), JITKT, 13 (2), 111124.

[20] Sirait, M., 2007, Penuntun Fitokimia dalam Farmasi, ITB Press, Bandung.

[21] Thompson, A., Cooper, J., and Ingram, Jr., L.L., 2006, Distribution of terpenes in heartwood and sapwood of loblolly pine, Forest. Prod. J., 56 (7-8), 46-48.

[22] Harborne, J.B., 1973, Phytochemical Methods A Guide to Modern Techniques of Plant Analysis, Chapman and Hall Ltd, London.

[23] Darmawan, A., Hanafi, M., Abbas, J., Dewi, R.T., Ernawati, T., Sugiwati, S., Fajriah, S., Megawati, Meiliawati, L., and Taufik, R., 2010, Isolasi, 
karakterisasi, dan elusidasi senyawa bioaktif antidiabetes dari daun cocor bebek (Kalanchoe pinnata (Lam) Pers.), Research Incentive Program Researcher and Engineer, Chemical Research Center, The Indonesian Institute of Sciences.

[24] Gurjar, H., Jain, S.K., Nandanwar, R., and Sahu, V.K., 2010, Phytochemical screening on the stem bark of Anthocephalus cadamba (Rox B) Miq., Int. J. Pharm. Sci. Res., 1 (7), 108-115.

[25] Yadao, N., Priya, C.L., and Rao, K.V.B., 2015, Carbohydrate hydrolyzing enzyme inhibitor property, antioxidant and phytochemical analysis of Cassia auriculata, Delonix regia and Vinca rosea Linn: An in vitro study, J. Appl. Pharm. Sci., 5 (5), 18-27.

[26] Wang, Y., Xiang, L., Wang, C., Tang, C., and He, X., 2013, Antidiabetic and antioxidant effects and phytochemicals of mulberry fruit (Morus alba L.) polyphenol enhanced extract, PLoS One, 8 (7), 110.

[27] Lee, H.H., Yin, L.J., Tai, H.M., and Jiang S.T., 2016, Facilitating the release of bionutrients from Morinda citrifolia (noni) by cellulase hydrolysis and lactic acid bacteria fermentation and their effects on $\alpha$-amylase and a-glucosidase activities, J. Mar. Sci. Technol., 24 (3), 648-655.

[28] Queiroz, D.P.K., Ferreira, A.G., Lima, A.S., Lima, E.P., and Lima, M.D., 2013, Isolation and identification of $\alpha$-glucosidase, $\alpha$-amylase and lipase inhibitors from Hortia longifolia, Int. J. Pharm. Pharm. Sci., 5 (3), 336-339.

[29] Verma, A., Dewangan, P., Kesharwani, D., and and Kela, S.P., 2013, Hypoglycemic and hypolipidemic activity of Scopoletin (coumarin derivative) in streptozotocin induced diabetic rats, Int. J. Pharm. Sci. Rev. Res., 22 (1), 79-83.

[30] Kumar, M., Rawat, P., Rahuja, N., Srivastava, A.K., and Maurya, R., 2009, Antihyperglycemic activity of phenylpropanoyl esters of catechol glycoside and its dimers from Dodecadenia grandiflora, Phytochemistry, 70 (11-12), 14481455.

[31] Lordan, S., Smyth, T.J., Soler-Vila, A., Stanton, C., and Ross, R.P., 2013, The a-amylase and $\alpha$ glucosidase inhibitory effects of Irish seaweed extracts, Food. Chem., 141 (3), 2170-2176.

[32] Zhang, Z., Luo, A., Zhong, K., Huang, Y., Gao, Y., Zhang, J., Gao, H., Xu, Z., and Gao, X., 2013, aGlucosidase inhibitory activity by the flower buds of Lonicera japonica Thunb, J. Funct. Foods, 5 (3), 1253-1259.

[33] Darmawan, A., Kosela, S., Kardono, L.B.S., and Syah, Y.M., 2012, Scopoletin, a coumarin derivative compound isolated from Macaranga gigantifolia Merr., J. Appl. Pharm. Sci., 2 (12), 175-177. 